\title{
RECENT ADVANCES ON EVOLUTION OF POLLINATION SYSTEMS AND REPRODUCTIVE BIOLOGY OF VANILLOIDEAE (ORCHIDACEAE)
}

\author{
EMERSON R. PANSARIN \\ Departamento de Biologia, Faculdade de Filosofia, Ciências e Letras, Universidade de São Paulo, \\ Av. Bandeirantes 3900, 14040-901, Ribeirão Preto, SP, Brazil • epansarin@ffclrp.usp.br
}

\begin{abstract}
Vanilloideae as currently circumscribed comprises nine genera and two tribes: Vanilleae and Pogonieae. The pantropical genus Vanilla has been frequently assumed to be natural on the basis of its climbing habit and lateral inflorescences. However, the inclusion of the rare Dictyophyllaria dietschiana in phylogenetic analyses makes the genus Vanilla paraphyletic. Within Pogonieae, phylogenetic analyses show that inclusion of Pogoniopsis turns the tribe paraphyletic. All analyses reveal that Pogoniopsis is closely related to members of Epidendroideae. Members of Pogonieae are pollinated by several groups of solitary and social bees, two pollination systems being recognized: reward-producing and deceptive. Molecular phylogeny suggests that the common ancestor to Pogonieae gave rise to two evolutionary lineages: one tropical with a condition of reward production; and one predominantly temperate-invading line with deceptive flowers. Reward-producing flowers characterize South and Central American clade (=Cleistes), while deceptive pollination is prominent in the clade including North American-Asiatic taxa plus Amazonian Duckeella. Species of "orchid bees" have been recorded as pollinators of the genus Vanilla (V. planifolia group and V. pompona group) in the Neotropics. In species of the $V$. pompona group, these bees are attracted by the fragrance of the flowers. Hummingbirds have been reported to pollinate some species of Vanilla. Vanilla insignis, V. odorata and V. planifolia are known to be pollinated through generalized food deception. Some species of Vanilla yield fruits through spontaneous selfpollination. This form of autogamy has been reported for V. griffithii, V. palmarum, V. planifolia, V. savannarum and $V$. bicolor. In Brazil, data on the pollination biology of Vanilla are scarce, but conclusive data are available for $V$. edwallii, which is pollinated by Epicharis (Apidae: Centridini). This species is rewardless, but male Epicharis are attracted to its flowers by their fragrance. Additionally, the Brazilian V. dubia and E. sclerophyllum are pollinated by bees. The mentum region of $V$. dubia and $V$. edwallii is dry, whereas that of E. sclerophyllum presents a small quantity of nectar. Flowers of E. sclerophyllum are scentless, while those of $V$. dubia are odoriferous. Vanilla dubia and V. edwallii are self-compatible and need a pollinator to yield fruits. In contrast, Epistephium sclerophyllum sets fruits through spontaneous self-pollination, but biotic pollination also occurs. Both species are primarily adapted to pollination by euglossine bees. Pollination by Euglossini seems to have evolved at least twice along the evolution of Vanilleae. Furthermore, shifts between rewarding and rewardless flowers and between autogamous and allogamous species have been reported among vanillas.
\end{abstract}

KEY wORDS: Flower reward, food deception, Pogonieae, pollination biology, reproduction, Vanilleae

Phylogenetic relationships within Vanilloideae. Since the first comprehensive study published by Darwin (1892), the pollination systems displayed by orchid flowers have inspired biologists over the centuries. Nowadays, several research groups have focused on understanding pollination biology and evolution of pollination systems of orchids based on the combination of phylogenic hypothesis with morpho-anato- mical studies and several kinds of ecological data (see Pansarin et al. 2012). In some orchid groups, however, these data are very difficult to be obtained since many pecies are not cultivable and investigations need to be made exclusively in the field. This is the case for Vanilloideae, a subfamily where data on the natural history of several genera, such as Cleistes for instance, must be collected exclusively in the natural environment. 

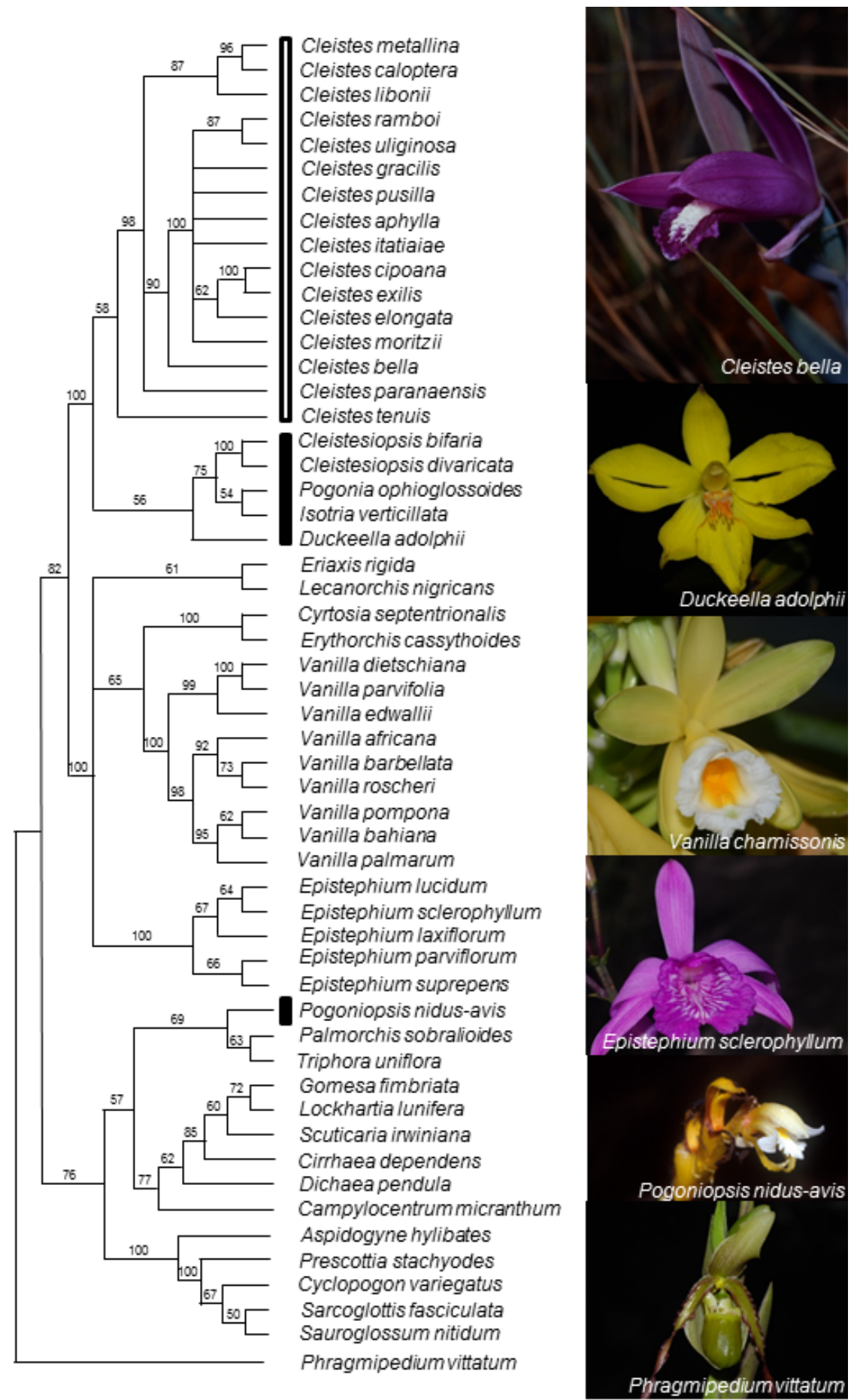

FigURE 1. Maximum parsimony analyses based on combined 5.8S, 18S and 26S (nrDNA) regions of Pogonieae (Orchidaceae,

Vanilloideae). Bootstrap values $>50$ (MP) are given above branches. Vertical bars refer to tribe Pogonieae. Empty bars = nectar-producing Pogonieae (i.e., genus Cleistes). Full bars = rewardless Pogonieae. Note that Vanilloideae and Pogonieae, as currently circumscribed, are paraphyletic. Adapted from Pansarin et al. (2012). 



Figure 2. Vanilla dietschiana. A. Habit. Note the stem with monopodial (pseudosympodial) growth; B. Flower. Note the green sepals and petals and the white tubular labellum with longitudinal keels on the median portion.

Vanilloideae has been considered as a monophyletic subfamily (Cameron, 2003, 2009). However, the inclusion of Pogoniopsis in the analysis turns Vanilloideae paraphyletic (Fig. 1; adapted from Pansarin et al. 2012). Vanilloideae is currently divided into the tribes Vanilleae and Pogonieae (Cameron 2003, 2009; Pansarin et al. 2012). Vanilleae is subcosmopolitan in distribution and comprises nine genera, namely Clematepistephium, Cyrtosia, Epistephium, Eriaxis, Erythrorchis, Galeola, Lecanorchis, Pseudovanilla and Vanilla. The genus Vanilla is pantropical and has been frequently assumed to be natural on the basis of its climbing habit and lateral inflorescences (Cameron \& Molina 2006). However, the inclusion of the rare Dictyophyllaria dietschiana in the phylogenetic analyses makes the genus Vanilla paraphyletic (Pansarin 2010a, 2010b; Pansarin et al. 2012). Thus, Dictyophyllaria has been restored to Vanilla (Pansarin 2010a, 2010b; Pansarin et al. 2012). Vanilla dietschiana (Figs. 2A-B) is closely related to $V$. edwallii and $V$. parvifolia by floral and vegetative characters. Vanilla dietschiana is terrestrial, with monopodial (pseudosympodial) non-climbing habit. Its reduced leaves are pale green, reticulate- veined and membranous, such as in $V$. edwallii and $V$. parvifolia (Pansarin 2010b).

The North American-Asiatic Pogonieae includes five genera: Cleistes, Cleistesiopsis, Duckeella, Isotria and Pogonia (Pansarin et al. 2008, 2012). The genus Duckeella, which is endemic to Amazonia, frequently emerges as sister to the rest of Pogonieae (Pansarin et al., 2008, Pansarin et al. 2012). The genera Isotria, Pogonia, and Cleistesiopsis (Pansarin \& Barros, 2008) form a temperate group, sister to the tropical Cleistes, a robustly supported South-Central American clade (e.g., Pansarin et al. 2008, Pansarin et al. 2012).

Pogoniopsis, a myco-heterotrophic genus endemic to Brazilian forests, has been included in the tribe Pogonieae (Cameron, 2003, 2009), which has been assumed as monophyletic (Cameron \& Chase 1999; Cameron et al. 1999). However, a phylogenetic analyses show that inclusion of Pogoniopsis turns the tribe paraphyletic (Fig. 1; Pansarin et al. 2012). All analyses reveal that Pogoniopsis is closely related to members of Epidendroideae (Fig. 1; Pansarin et al. 2012). Pogoniopsis have a sympodial habit with reduced leaves. The inflorescence is a terminal raceme (Fig. 3A). The flowers are whitish and the 

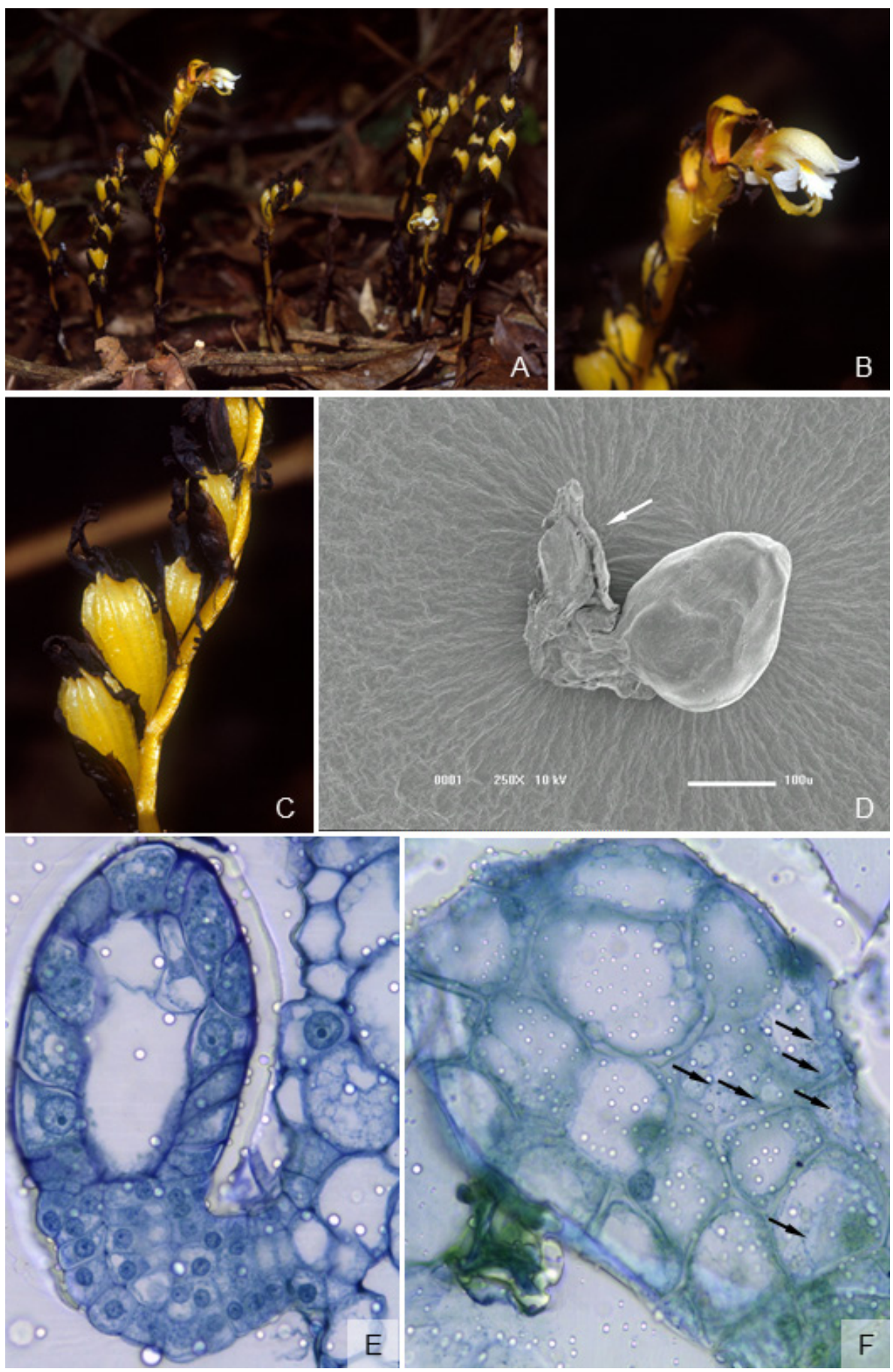

Figure 3. Pogoniopsis nidus-avis. A. Habit; B. Flower; C. Fruits (note the persistent perianth parts); D. Scanning Electron

Microscopy (SEM) image of a sclerified seed. Note the remnant of the funiculus (arrow); E. Longitudinal cut of a seed stained with toluidine blue. Note the funiculus and the placenta; F. Longitudinal section of an ovule stained with toluidine blue showing the cells with large nuclei and densely stained cytoplasm. Note the granules, which are related to embryo nutrition (arrows). 
perianth is persistent (Figs. 3A-B). The labellum is 3-lobed and presents clusters of yellow hairs on its mid portion. The lateral lobes are falcate and entire, while the apical lobe is spatulate and fringed. The pollen of Pogoniopsis nidus-avis is free and the anther is versatile. Furthermore, the flowers are characterized by the absence of the abscission zone between perianth and ovary (a characteristic common to members of Vanilloideae; Pansarin \& Barros 2008, Pansarin et al. 2008, 2012), rewardless, flowers opening in succession, with fleshy and indehiscent fruits (Fig. 3C), and ovoid seeds with a crustose seed coat (Figs. 3C-F). The seeds of Pogoniopsis possess characteristics also found in Vanilla and Palmorchis. Longitudinal cuts of the seeds and ovules of Pogoniopsis reveal the cells possess large nuclei and densely stained cytoplasm. The cytoplasm possesses granules, related to embryo nutrition (E.R. Pansarin, unpubl. data; Figs. 3E-F).

Reproductive biology within Pogonieae. Floral biology and pollination systems of Pogonieae is currently well known, since all genera of this subtribe has been studied on this subject. Among the North American-Eastern Asiatic clade data are available for Pogonia ophioglossoides (Thien \& Marcks 1972), Pogonia japonica (Matsui et al. 2001), Isotria verticillata and I. medeoloides (Mehrhoff 1983), in addition to Cleistesiopsis divaricata (syn. Cleistes divaricata) and Cleistesiopsis bifaria (syn. Cleistes bifaria; Gregg 1989, 1991a, 1991b). Cleistesiopsis bifaria and C. divaricata are pollinated by workers of Bombus and Megachile (Gregg 1989, 1991a, 1991b). Isotria verticillata is pollinated by small Halictidae, Anthophoridae and Andrenidae bees, while $I$. medeoloides is automatically self-pollinated (Mehrhoff 1983). Pogonia ophioglossoides is pollinated by queens and workers of bumblebees (Thien \& Marcks 1972).

Pollination data regarding South-Central American clade (i.e., genus Cleistes) are available to several species, including $C$. libonii (syn. Cleistes macrantha; Fig. 4A), C. aphylla (Fig. 4B), C. exilis (Fig. 4C), C. pusilla, C. paranaensis (Fig. 4D), C. bella (Fig. 4E) and C. rosea (Fig. 4F) (Pansarin 2003; Pansarin et al. 2012). The species are pollinated by solitary or social bees, except Cleistes libonii (Fig. 4A), which is copollinated by hermit hummingbirds (Pansarin 2003). According to Pansarin et al. (2012), the reproductive phenology, the flowering strategies and the pollination mechanisms are similar among Brazilian Cleistes. In the spring (from October to November), each plant produces one unbranched aerial stem, with one erect and terminal raceme. Flowering generally occurs two or three months later, in the rainy season, from late December to early April. During a single flowering period, the species of Cleistes generally have three or four blooming peaks, each showing a precise synchronism in which all mature buds of most individuals within a population open simultaneously in the early morning. Flowering synchronism, as observed in all studied species of Cleistes, also has been recorded for basal Epidendroids, such as Triphora trianthophora (Medley 1979) and Psilochilus modestus (Pansarin \& Amaral 2008).

The flowers of Cleistes possess two nectar glands at the base of the labellum, and a longitudinal and central crest with clusters of yellow or white colored hairs or papillae on the upper third, which act as a nectar guide. The column is parallel-disposed to the lip and presents a terminal versatile anther with two yellow clusters of free monads. The stigmatic surface is generally flat and possesses small and hyaline papillae. All studied species of Cleistes offer nectar as reward, which is produced by two nectar glands located on the base of the labellum. These glands are densely vascularized and the nectar is secreted along the nectary surface (Pansarin et al. 2012).

Duckeella adolphii possess lateral inflorescences with yellow flowers. The perianth parts are membranous. The basal portion of the labellum possesses a central crest covered by multicellular papillae. The elaiophor-like papillae are constituted by non-secretory cells.

Species of Cleistes and D. adolphii are dependent on pollen vectors for fruit setting. Coherent with the similarity among the floral morphology of the Cleistes flowers, the pollination mechanism is similar among Cleistes. The bees land on the lip apex and probe for nectar at its base. While the bees leave the flower, the anther is disarticulated with the scutellum and free pollen monads are placed on the scutum. Afterwards, the anther returns to the original position. In Duckeella adolphii the bees land directly on the central crest of the labellum, i.e., on the elaiophor-like calluses (Pansarin 2003; Pansarin et al. 2012). Although the 

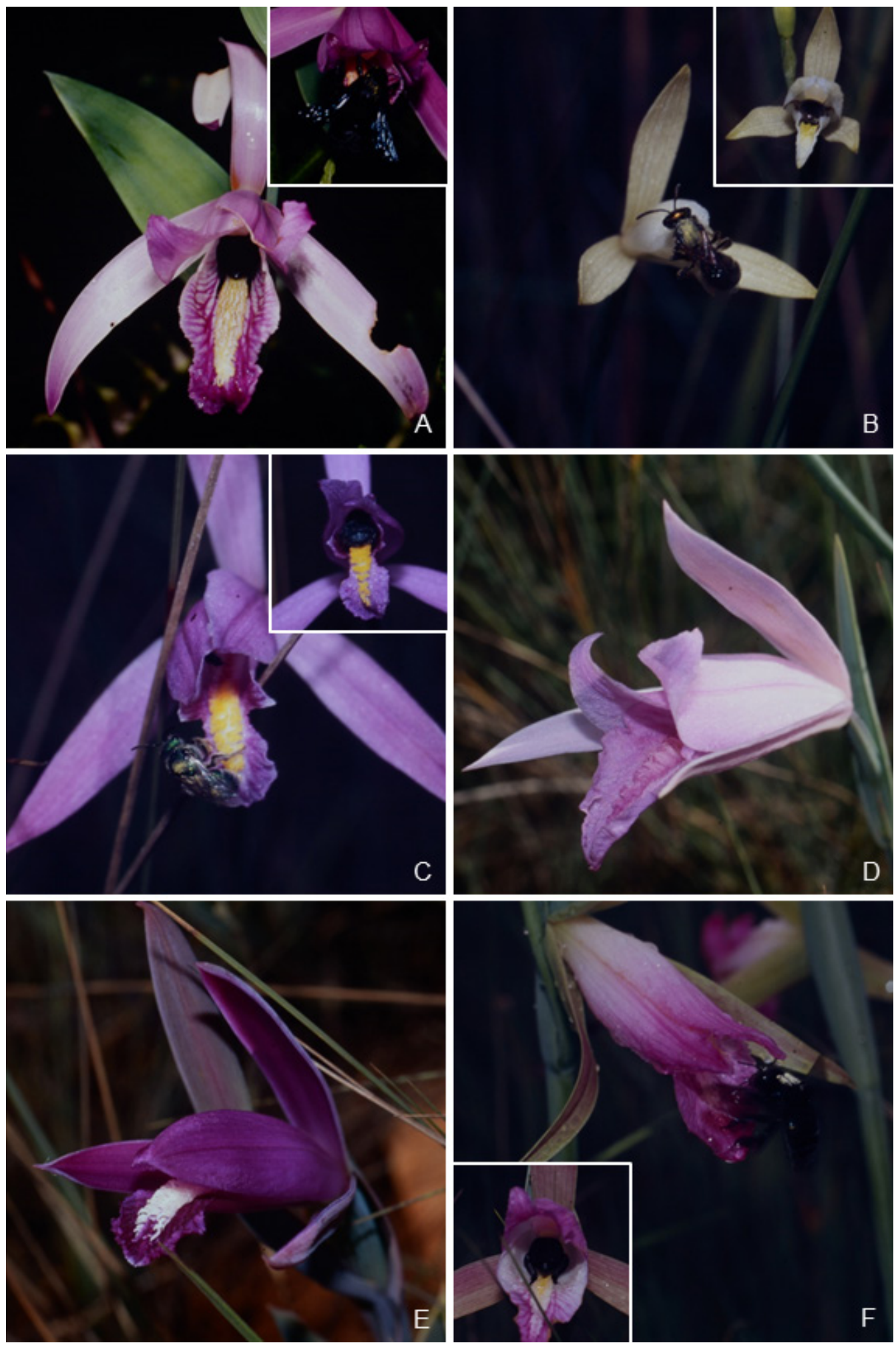

LANKESTERIANA 16(2). 2016. (C) Universidad de Costa Rica, 2016. 
presence of nectaries has been recorded at the base of the lip of Cleistes (Pansarin 2003. Pansarin et al. 2012), Cleistesiopsis divaricata and Isotria verticillata are pollinated by food deception, although both species bear nectar guides (Mehrhoff 1983; Gregg 1991a) and floral glands have been reported at the lip base of Isotria verticillata (Correll 1950). A hair-like cluster on the lip simulates pollen and attracts pollinators by deceit to the flowers of Pogonia (Dressler 1993) and Cleistesiopsis bifaria (Gregg 1989).

Like the North American genera Cleistesiopsis, Pogonia and Isotria verticillata (Thien \& Marcks 1972, Mehrhoff 1983, Gregg 1989, 1991a), the South American Cleistes are pollinated exclusively by bees (Pansarin 2003, Pansarin et al. 2012). Visitation only on the first day of flower opening, even in species with longer lasting flowers, is probably related to the accumulation of the total volume of nectar at this time, no nectar production taking place afterwards. An exception is $C$. libonii whose flowers were visited also on the second day of anthesis (Pansarin 2003).

In Pogonieae the pollen is free and the pollen mass from a single flower, deposited on the scutum of a bee, may pollinate several flowers (Gregg 1991a, 1991b). Furthermore, some authors agree that flowering synchronism combined with the production of short-lived flowers may favor cross-pollination within a population (Medley 1979, Pansarin \& Amaral 2008). According to Catling and Catling (1991), this kind of synchrony is an important strategy favoring cross-pollination in plants with one or few-flowered inflorescences. In fact, when all flowers in a population open simultaneously (i.e., gregarious plants) the floral display for pollinator attraction is maximized (Pansarin et al. 2012).

The genus Isotria with floral glands at the lip base (Correll 1950, Cameron 2003) appears as sister to the remaining North American and Asiatic Pogonieae in some phylogenetic analyses based on chloroplast DNA (Pansarin et al. 2008). In the Amazonian Duckeella adolphii and in all other North American and Asiatic species (Pogonia, Cleistesiopsis divaricata and $C$. bifaria), floral glands are absent (see Thien \& Marcks 1972, Gregg, 1989, 1991a, 1991b, Matsui et al. 2001). It has been suggested that in Orchidaceae deceptive mechanisms evolved from reward pollination systems (Dafni 1984, Ackerman 1986, Nilsson 1992). In the case of Pogonieae, reward production could be tested on the basis of molecular phylogeny. Our data suggest that ancestors of Pogonieae gave rise to two lineages, one of them spreading into tropical America, eventually originating the extant Neotropical Cleistes species with nectariferous flowers, and another one predominantly North American-Asiatic, but including the Amazonian Duckeella, pollinated through deceptive mechanisms (Fig. 1).

Some author argue that nectar can be energetically expensive and resources for reward production could be allocated more usefully for other functions capable of increasing fitness in species pollinated through deception (Boyden 1982, Ackerman 1986). The main problem with this hypothesis is that in many orchids, fitness is pollination limited, rather than resource limited (Calvo \& Horvitz 1990, Calvo 1993). Furthermore, although few studies have been performed on this subject (see Pyke 1991), the rate of nectar production tends to be lower in short-lived than in long-lived flowers (Johnson \& Nilsson 1999). Coherently, flowers in nectar-producing tropical Cleistes are shorter lasting than in the deceptive Isotria, Pogonia, Cleistesiopsis divaricata and C. bifaria (Thien \& Marcks 1972, Mehrhoff 1983, Gregg, 1989, 1991b). On the other hand, in comparison with mechanisms involving nectar production, rewardlessness may reduce the visitation frequency, consequently lowering the reproductive success (Dafni 1984, Ackerman 1986, Johnson \& Nilsson 1999, Johnson, 2000). Another consequence of deceptive mechanisms may be the reduction of natural fruit set and thus fruits are formed through geitonogamy

Left, FiguRE 4. A-F. Species of Pogonieae and its pollinators. A. Bombus atratus probing for nectar at the lip base of Cleistes libonii. The detail shows the bee leaving a flower. Note some pollen on its scutum; B. Dialictus sp. leaving a flower of C. aphylla. Note the pollen on its scutum. The detail shows the bee probing for nectar at the lip base; C. Augochlora sp. leaving a flower of $C$. exilis. Note the pollen deposited on its scutum. The detail shows the bee probing for nectar at the lip base; D. Flower of C. paranaensis; E. Flower of C. bella in diagonal view showing the white hairs on the central labellar crest; F. Xylocopa sp. with its scutum covered with a pollen load leaving a flower of C. rosea. The detail is a Xylocopa sp. probing for nectar at the lip base. 
(Ackerman 1986, Johnson \& Nilsson 1999, Johnson 2000; Smithson 2002, Pansarin \& Pansarin 2014a). These claims are supported by comparing plants from reward-producing and deceptive Pogonieae clades (Pansarin et al. 2012). North-American Pogonieae have low reproductive success (Thien \& Marcks, 1972, Mehrhoff 1983, Gregg 1989, 1991b), comparing to Brazilian species (E.R. Pansarin, unpubl. data). In certain years, fruit set of some species of Cleistes (e.g., C. rosea, C. libonii, C. metallina, and C. ramboi) reached nearly $100 \%$ (E.R. Pansarin, unpubl. data). It is worth mentioning that production of one to few short-lived flowers by each inflorescence of Central and South American Cleistes and the precise flowering synchronization tend to reduce the occurrence of selfpollination and geitonogamy (Pansarin et al. 2012). Furthermore, orchids with soft pollen (such as occurs in all Pogonieae species; Cameron \& Chase 1999, Pansarin et al. 2008) apparently are not prone to fruit set through geitonogamous self- (Johnson \& Nilsson 1999). Self-pollination resulting from geitonogamy is considered a mechanism of fitness reduction because of depression by inbreeding and pollen loss.

Reproductive biology within Vanilleae. Data on reproductive biology available on Vanilleae are scarce. Studies on pollination biology within Vanilleae have been performed predominantly on species of Vanilla (e.g., Lubinsky et al., 2006, 2010; Pansarin \& Pansarin, 2014b; Pansarin et al., 2014), which is the most diverse and economically important genus within Vanilloideae (Correll, 1953). The pollination system of Epistephium has been investigated more recently (Pansarin \& Pansarin, 2014b). Within Vanilleae, euglossine bees have been recorded as pollinators of species of Vanilla (i.e., V planifolia group and $V$. pompona group) in the Neotropics (e.g., Lubinsky et al., 2006). Euglossine bees are also the main pollinators of Epistephium sclerophyllum and V. dubia in Brazil
(Pansarin et al., 2014). In species of the $V$. pompona group, these bees are attracted by the fragrance of the flowers. They then display the typical behavior of pollination by male euglossine bees. Hummingbirds have been reported to pollinate some species of Vanilla (Bouriquet, 1954), while bats have been assumed to pollinate $V$. chamissonis, although this affirmation has been contested (Fleming et al., 2009).

Vanilla insignis, $V$. odorata and V. planifolia are known to be pollinated through food deception (Soto Arenas et al., unpubl. data). Due to low fruit set in natural populations, cultivated plants of $V$. planifolia are selfpollinated by hand to increase the production of fruits (Soto Arenas 1999). Some species of Vanilla yield fruits through spontaneous self-pollination (van der Pijl \& Dodson 1966). This form of autogamy has been reported for $V$. griffithii, $V$. palmarum, populations of $V$. planifolia, and $V$. savannarum (see Pridgeon et al. 2003). Furthermore, flowers of a population of $V$. bicolor occurring in the Peruvian Amazon are obligatorily autogamous, producing fruits by cleistogamy (Van Dam et al. 2010).

Another Brazilian species that has been studied is V. edwallii (Fig. 5A), which is pollinated by Epicharis (Apidae: Centridini). Vanilla edwallii is rewardless, but male Epicharis are attracted to its flowers through the fragrance production (Pansarin et al. 2014). Additionally, Ruschi (1986) reports that $V$. chamissonis is visited by hummingbirds. However, in another study on this species, no pollinators were recorded, although fruits were observed in natural conditions (Reis et al. 2011). The flower morphology of Vanilla is very diverse, suggesting that different biotic vectors can act as pollinators of its species. Most species of Vanilla have tubular flowers where pollinators must enter through the tube formed by perianth and column (Dressler 1981). As occurs in Vanilla, the labellum margins of Epistephium are adnate to the column, resulting in a tubular flower (Dressler 1993).

Right, Figure 5. Species of Vanilleae and its pollinators. A. Flower of Vanilla edwallii. The detail shows a male Epicharis with pollen of $V$. edwallii on scutellum (arrow); B. Flower of $V$. dubia. The detail shows the cluster of penicillate hairs on the labellum (arrow); C. Labellum of Epistephium sclerophyllym in longitudinal section showing a Bombus (posed). Note it scutum just below the stigma and the articulated anther (arrow). The detail shows the cluster of hairs on the mid portion of the labellum (arrow); D. Labellum of Epistephium sclerophyllym in longitudinal section showing a bumblebee (posed). Note anther is disarticulated when the bee leaves the flower (arrow); E. Plebeia droryana collecting pollen directly from the anther. Note the corbiculae with pollen of the studied species; F. Iridopelma spider, capturing a pollinator (euglossine bee Eufriesea nigrohirta) on a flower of E. sclerophyllum. 

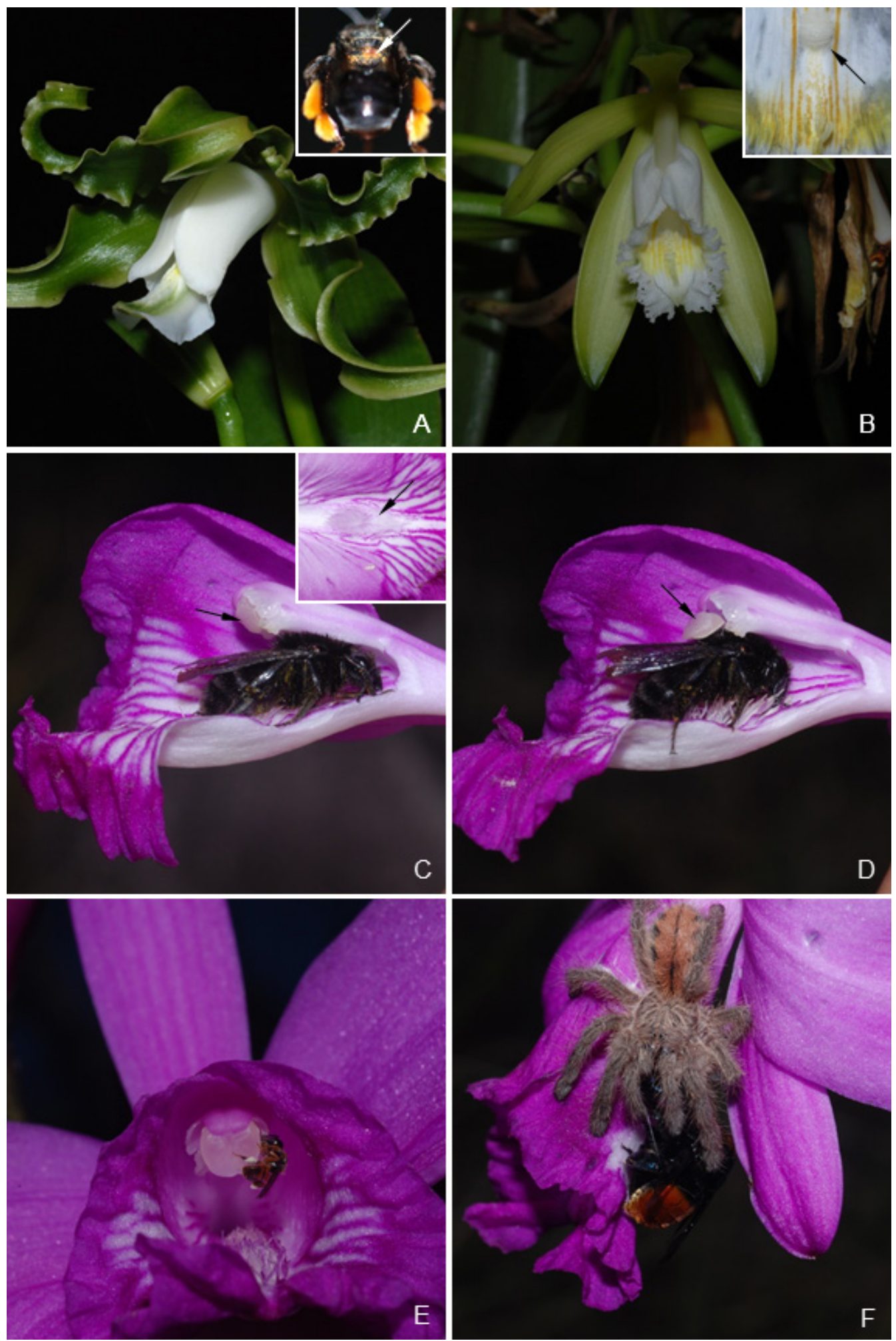
Studies on the secretory tissues of Vanilleae are very scarce. In the rewardless $V$. edwallii, the only secretory tissues are osmophores located on labellum (Pansarin et al. 2014). In V. edwallii, the labellar trichomes produce a heterogeneous substance formed by mucilage and volatile compounds in the mentum region, which is associated with pollinator attraction (Pansarin et al. 2014). In this species the fragrance is produced by multicellular epidermal papillae in the median portion of labellum, between the lateral lobes and the entrance of the mentum region (Pansarin et al. 2014). In Vanilla dubia, the trichomes at the labellum base also secrete volatile substances, which are associated with pollinator attraction (Pansarin \& Pansarin 2014b). Besides the oil droplets responsible for the odor of Vanilla dubia, starch grains were also observed within the labellar trichomes (Pansarin \& Pansarin 2014b). Starch is a polysaccharide stored by plant cells as an energy source (Gonzáles 1999). In contrast to that recorded for $V$. edwallii (Pansarin et al. 2014), in $V$. dubia, starch grains are exclusively present on the labellum trichomes (Pansarin \& Pansarin 2014b). Starch grains were already reported in association with osmophores in other Orchidaceae (Davies \& Turner 2004), but it is commonly associated with the production of mucilage in different plant organs, including orchids (Leitão \& Cortelazzo 2008).

Vanilla dubia is included in the Vanilla planifolia group, which includes vanillas with greenish flowers and a concave labellum with small papillae. The South American taxa of this group present a penicillate callus at the median portion of their labellum (Fig. 5B; Soto Arenas \& Cribb 2010). Within this group, in addition to $V$. dubia, food deception has also been reported in $V$. insignis, V. odorata and V. planifolia (Soto Arenas et al., unpubl. data). Pollination by male euglossine bees also has been reported for species of Vanilla hostmanii group: V. cribbiana, V. dressleri V. hameri; Vanilla pompona group: V. pompona, and Vanilla trigonocarpa group: V. trigonocarpa (Soto Arenas 1999, Pridgeon et al. 2003, Lubinsky et al. 2006, Soto Arenas \& Dressler 2010), although the mechanisms involving fragrance collection are still unknown (Rodolphe et al. 2011). In V. edwallii, although fragrance is related to attracting male Epicharis (Apidae: Centridini) patrolling the flowers and maintaining them nearby, it is not a harvestable resource. Vanilla edwallii is a species of the Vanilla parvifolia group, which includes the reticulate-veined vanillas (Soto Arenas \& Cribb 2010). Vanilla inodora (Vanilla mexicana group) seems to be pollinated by Xylocopa spp., although no evidence of pollination by these carpenter bees has been presented (Soto Arenas \& Dressler 2010). An unidentified species of Xylocopa was also recorded on $V$. edwallii, but it only acted as a floral visitor, perforating the base of the labellum in search for nectar (Pansarin et al. 2014).

The nectaries of Epistephium sclerophyllum do not present differentiated structures, as occurs in genus Cleistes, whose nectar is produced by nectar glands (Pansarin 2003, Pansarin et al. 2012). Rather, they are flat and composed by a single-layered epidermis with rectangular cells and three or four layers of (rectangular) parenchymal cells, supplied by vascular bundles, like in other orchids (Stpiczyńska \& Davies 2006). The similarity between the epidermal cells and the underlying parenchyma results in a nectary with a homogeneous pattern.

As recorded for Vanilla edwallii (Pansarin et al. 2014), Centridini bees (male Centris) were also observed patrolling the open flowers of Epistephium sclerophyllum waiting for females to mate. However, the flowers of E. sclerophyllum produce a minimal quantity of diluted nectar, which is probed by several bee species (Fig. 5C-F). In addition to nectar, pollen was directly collected from anthers by Meliponini bees (Fig. 5E; Pansarin \& Pansarin 2014b). Since, in most Orchidaceae, pollen is aggregated and forms indivisible pollinia (e.g., Dressler 1993), the offering of pollen as a resource is rare among orchids. The flowers of Episthepium sclerophyllum are scentless and bee attraction seems to be essentially visual, while the fragrance of the flowers of Vanilla dubia attracts male euglossine. Despite the presence of osmophores, the bees entering into the labellar tube appeared to be interested in nectar, not fragrances (Figs. 5CD; Pansarin \& Pansarin 2014b). The pollination mechanism in Epistephium is similar to that recorded in Cleistes (Pansarin 2003, Pansarin et al. 2012, Pansarin \& Pansarin 2014b). The bees land on the labellum apex and probe for nectar at its base (Fig. 5C). As the bees leave the flower, the anther is disarticulated with the scutellum and free pollen monads placed on the thorax (Fig. 5D). Afterwards, the anther returns to the original position (Fig. 5C). Although pollination by other 
bee groups can occur (E. sclerophyllum; Figs. 5CF), the flowers of both studied species are adapted to pollination by euglossines (Fig. 5F). Within Vanilleae, data are still inconclusive, but Epistephium, which, as recorded here for E. sclerophyllum, has nectariferous flowers, emerges as a sister to the rest of tribe. Within the monophyletic genus Vanilla, although more data on pollination biology are still needed, deceptive and rewarding species have been recorded (see Pansarin et al. 2014), suggesting that shifts between rewarding and rewardless species have happened more than once during the evolution of a genus (Fig. 1; Pansarin et al. 2012). This is reinforced by our recent observations, in the Amazonian forest, on the pollination biology of Vanilla palmarum, whose flowers produce nectar and are visited by hummingbirds (E.R. Pansarin and A.W.C. Ferreira, unpubl. data).

Although studies on vanilloid species pollinated by biotic vectors are scarce (exceptions in Lubinsky et al. 2006, 2010, Pansarin \& Pansarin 2014b, Pansarin et al. 2014), spontaneous self-pollination has been recorded for some taxa, as V. bicolor (Van Dam et al. 2010), Vanilla griffithii, V. palmarum and $V$. savannarum (Pridgeon et al. 2003). Probably this is also the case with Epistephium sclerophyllum, whose stigmatic surface is not clearly separated from the anther (Pansarin \& Pansarin 2014b). In E. sclerophyllum despite the formation of fruits through autogamy, bees act as pollinators, thus contributing to the possible formation of fruits trough cross-pollination.

Acknowledgements. The author thanks Fundação de Amparo à Pesquisa do Estado de São Paulo - FAPESP (grants 00/11015-9 and 07/07445-7), and Conselho Nacional do Desenvolvimento Científico e Tecnológico (grant 454490/2015-1) for funds provision.

\section{LiTERATURE CITED}

Ackerman, J. D. (1986). Mechanisms and evolution of fooddeceptive pollination systems in orchids. Lindleyana 1 , 108-113.

Bouriquet, G. (1954). Culture. In: G. Bouriquet (Ed.). Le vanillier et la vanille dans le monde (pp. 430-458). Paris: Paul Lechevalier.

Boyden, T. C. (1982). The pollination biology of Calypso bulbosa var. americana (Orchidaceae): initial deception of bumblebee visitors. Oecologia 55, 178-184.

Calvo, R. N. \& Horvitz, C. C. (1990). Pollinator limitation, cost of reproduction, and fitness in plants, a transition matrix demographic approach. The American Naturalist 136, 499-516.

Cameron, K. M. (2003). Vanilloideae. In: A. Pridgeon, P. Cribb, M. W. Chase \& F. Rasmussen (Eds.). Genera Orchidacearum (pp. 281-334). Oxford: Oxford University Press.

Cameron, K. M. (2009). On the value of nuclear and mitochondrial gene sequences for reconstructing the phylogeny of vanilloid orchids (Vanilloideae, Orchidaceae). Annals of Botany 104, 377-385.

Cameron, K. M. \& Chase, M. W. (1999). Phylogenetic relationships of Pogoniinae(Vanilloideae, Orchidaceae): an herbaceous example of the eastern North America eastern Asia phytogeographic disjunction. Journal of Plant Research 112, 317-329.

Cameron, K. M., Chase, M. W., Whitten, W. M., Kores, P. J., Jarrell, D. C., Albert, V. A., Yukawa, T., Hills, H. G. \& Goldman, D. H. (1999). A phylogenetic analysis of the Orchidaceae: evidence from $r b c \mathrm{~L}$ nucleotide sequences. American Journal of Botany 86, 208-224.

Cameron, K. \& Molina, M. C. (2006). Photosystem II gene sequences of $p s b B$ and $p s b C$ clarify the phylogenetic position of Vanilla (Vanilloideae, Orchidaceae). Cladistics 22, 239-248.

Catling, P. M. \& Catling, V. R. (1991). A synopsis of breeding systems and pollination in North American orchids. Lindleyana 6, 187-210.

Correll, D. S. (1950). Native orchids of North America. Waltham: Chronica Botanica.

Correll, D. S. (1953). Vanilla- its history, cultivation and economic importance. Economic Botany 7, 291-358.

Dafni, A. (1984). Mimicry and deception in pollination. Annual Review of Ecology and Systematics 15, 259-278.

Darwin, C. (1892). The various contrivances by which orchids are fertilized by insects. $2^{\mathrm{ND}}$ ed. rev. (1st ed. 1862). New York: Appleton.

Dressler, R. L. (1981). The orchids: natural history and classification. Cambridge: Harvard University Press.

Dressler, R. L. (1993). Phylogeny and Classification of the Orchid Family. Portland: Dioscorides Press.

Fleming, T. H., Geiselman, C. \& Kress, W. J. (2009). The evolution of bat pollination: a phylogenetic perspective. Annals of Botany 104, 1017-1043.

Davies, K. L. \& Turner, M. P. (2004). Morphology of floral papillae in Maxillaria Ruiz \& Pav. (Orchidaceae). Annals of Botany 93, 75-86.

Gonzáles, M. L. (1999). Polisacáridos. In: A. M. Del Fresno (Ed.). Farmacognosia General (pp. 335). Madrid: Ed. Síntesis.

Gregg, K. B. (1989). Reproductive biology of the orchid Cleistes divaricata (L.) Ames var. bifaria Fernald growing in a West Virginia meadow. Castañea 54, 57-78. 
Gregg, K. B. (1991a). Reproductive strategy of Cleistes divaricata (Orchidaceae). American Journal of Botany 78, 350-360.

Gregg, K. B. (1991b). Defrauding the deceitful orchid: pollen collection by pollinators of Cleistes divaricata and C. bifaria. Lindleyana 6, 214-220.

Johnson, S. D. (2000). Batesian mimicry in the nonrewarding orchid Disa pulchra, and its consequences for pollinator behavior. Biological Journal of the Linnean Society 71, 119-132.

Johnson, S. D. \& Nilsson, L. A. (1999). Pollen carryover, geitonogamy, and the evolution of deceptive pollination systems in orchids. Ecology 80, 2607-2619.

Leitão, C. A. E. \& Cortelazzo, A. L. (2008). Structural and histochemical characterization of the colleters of Rodriguezia venusta (Orchidaceae). Australian Journal of Botany 56, 161-165.

Lubinsky, P., Van Dam, M. H. \& Van Dam, A. R. (2006). Pollination of Vanilla and evolution in Orchidaceae. Lindleyana 75, 926-929.

Lubinsky, P., Romero-González, G. A., Heredia, S. M. \& Zabel, S. (2010). Origins and patterns of vanilla cultivation in tropical America (1500-1900): no support for an independent domestication of vanilla in South America. In: D. Havkin-Frenkel \& F. C. Belanger (Eds.). Handbook of vanilla science and technology (pp. 117-138). Oxford: Wiley-Blackwell.

Matsui, K., Ushimaru, T. \& Fujita, N. (2001). Pollinator limitation in a deceptive orchid, Pogonia japonica, on a floating peat mat. Plant Species Biology 16, 231-235.

Medley, M. E. (1979). Some aspects of the life story of Triphora trianthophora (Sw.) Rydb. (Three birds orchid) with reference to its pollination. MD Thesis. St Andrews: Andrews University.

Mehrhoff, L. A. (1983). Pollination in the genus Isotria (Orchidaceae). American Journal of Botany 70, 1444 1453.

Nilsson, L. A. (1992). Orchid pollination biology. Trends in Ecology \& Evolution 7, 255-259.

Pansarin, E. R. (2003). Biologia floral de Cleistes macrantha (Barb. Rodr.) Schltr. (Orchidaceae: Vanilloideae: Pogoniinae). Revista Brasileira de Botânica 26, 73-80.

Pansarin, E. R. (2010a). Vanilla dietschiana, returns from Dictyophyllaria. Orchids 79, 106-109.

Pansarin, E. R. (2010b). Taxonomic notes on Vanilleae (Orchidaceae: Vanilloideae): Vanilla dietschiana, a rare south American taxon transferred from Dictyophyllaria. Selbyana 30, 198-202.

Pansarin, E. R. \& Amaral, M. C. E. (2008). Pollen and nectar as a reward in the basal epidendroid Psilochilus modestus (Orchidaceae: Triphoreae): A study of floral morphology, reproductive biology and pollination strategy. Flora (Jena) 203, 474-483.
Pansarin, E. R. \& Barros, F. (2008). Taxonomic notes on Pogonieae (Orchidaceae): Cleistesiopsis, a new genus segregated from Cleistes, and description of two new South American species, Cleistes batistana and $C$. elongata. Kew Bulletin 63, 441-448.

Pansarin, E. R., Salatino, A. \& Salatino, M. L. F. (2008). Phylogeny of South American Pogonieae (Orchidaceae, Vanilloideae) based on sequences of nuclear ribosomal (ITS) and chloroplast ( $p s a B, r b c L$ rps 16, and $\operatorname{trnL}-F$ ) DNA with emphasis on Cleistes and discussion of biogeographic implications. Organisms, Diversity and Evolution 8, 171-181.

Pansarin, E. R., Salatino, A., Pansarin, L. M. \& Sazima M. (2012). Pollination systems in Pogonieae (Orchidaceae: Vanilloideae): A hypothesis of evolution among reward and rewardless flowers. Flora (Jena) 207, 849-861.

Pansarin, E. R., Aguiar, J. M. R. B. V. \& Pansarin, L. M. (2014). Floral biology and histochemical analysis of Vanilla edwallii Hoehne (Orchidaceae: Vanilloideae): an orchid pollinated by Epicharis (Apidae: Centridini). Plant Species Biology 29, 242-252.

Pansarin E. R. \& Pansarin L. M. (2014a). Reproductive biology of Epidendrum tridactylum (Orchidaceae: Epidendroideae): a reward-producing species and its deceptive flowers. Plant Systematics and Evolution 300, 321-328.

Pansarin, E. R. \& Pansarin, L. M. (2014b). Floral biology of two Vanilloideae (Orchidaceae) primarily adapted to pollination by euglossine bees. Plant Biology (Stuttgart) 16, 1104-1113.

Pridgeon, A. M., Cribb, P. J., Chase, M. W. \& Rasmussen, F. N. (2003). Genera Orchidacearum, vol. 3, Orchidoideae (Part 2), Vanilloideae. London: Oxford University Press.

Pyke, G. H. (1991). What does it cost a plant to produce floral nectar? Nature 350, 58-59.

Reis, C. A. M., Brondani, G. E. \& Almeida, M. de (2011). Biologia floral e propagação vegetativa de baunilha. Scientia Agraria Paranaensis 10, 69-82.

Rodolphe, G., Séverine, B., Michel, G. \& Pascale, B. (2011). Biodiversity and evolution in the Vanilla genus. In: O. Grillo \& G. Venora (Eds.). The dynamical processes of biodiversity - case studies of evolution and spatial distribution (pp. 1-27). Rijeka: InTech.

Ruschi, A. (1986). Aves do Brasil. Rio de Janeiro: Expressão e Cultura.

Smithson, A. (2002). The consequences of rewardlessness in orchids: reward-supplementation experiments with Anacamptis morio (Orchidaceae). American Journal of Botany 89, 1579-1587.

Soto Arenas, M. A. (1999). Filogeografia y recursos genéticos de las vanillas de México. México 
DF: Instituto Chinoin AC. Informe final SNIBCONABIO proyecto No. J101.

Soto Arenas, M. A. \& Cribb, P. (2010). A new infrageneric classification and synopsis of the genus Vanilla Plum. ex Mill. (Orchidaceae: Vanillinae). Lankesteriana 9, 355-398.

Soto Arenas, M. A. \& Dressler, R. L. (2010). A revision of the Mexican and Central American species of Vanilla Plumier ex Miller with a characterization of their ITS region of the nuclear ribosomal DNA. Lankesteriana 9, 285-354.

Stpiczyńska, M. \& Davies, K. L. (2006). Nectary structure in Symphyglossum sanguineum (Rchb.f.) Schltr. (Orchidaceae). Acta Agrobotanica 59, 7-16.
Thien, L. B. \& Marcks, B. G. (1972). The floral biology of Arethusa bulbosa, Calopogon tuberosus, and Pogonia ophioglossoides (Orchidaceae). Canadian Journal of Botany 50, 2319-2325.

Van Dam, A. R., Householder, J. E. \& Lubinsky, P. (2010). Vanilla bicolor Lindl. (Orchidaceae) from the Peruvian Amazon: auto-fertilization in Vanilla and notes on floral phenology. Genetic Resources and Crop Evolution 57, 473-480.

van der Pijl, L. \& Dodson, C. H. (1966). Orchid flowers, their pollination and evolution. Florida: University of Miami Press. 
LANKESTERIANA • V SCIENTIFIC CONFERENCE ON ANDEAN ORCHIDS 